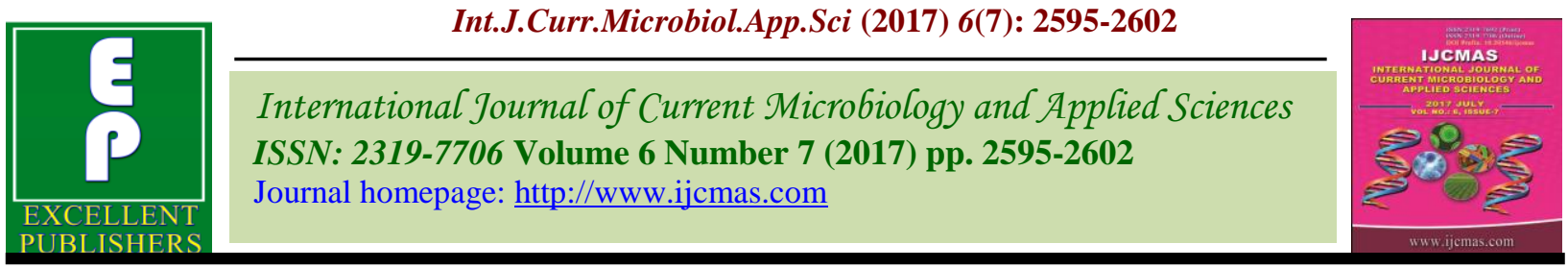

Original Research Article

https://doi.org/10.20546/ijcmas.2017.607.306

\title{
A Study on Cauliflower (Brassica oleracea var. botrytis) Based Intercropping System
}

\author{
J. Kabiraj*, R. Das, S.P. Das and A.R. Mandal \\ Department of Vegetable Crops, Faculty of Horticulture, Bidhan Chandra Krishi \\ Viswavidyalaya, Mohanpur, Nadia - 741252 (W.B.), India \\ *Corresponding author
}

\section{A B S T R A C T}

\begin{tabular}{l} 
Ke y w o r d s \\
Cauliflower, \\
Intercropping, \\
LER, French bean, \\
Pea, Carrot, Beet, \\
Palak, Coriander. \\
\hline Article Info \\
\hline $\begin{array}{l}\text { Accepted: } \\
\text { 23 June } 2017 \\
\text { Available Online: } \\
\text { 10 July } 2017\end{array}$ \\
\hline
\end{tabular}

A field experiment was carried out at Horticulture Research Station, Mondouri of Bidhan Chandra Krishi Viswavidyalaya, Mohanpur, Nadia, West Bengal, during winter seasons of 2013-2014 and 2014-2015 to study the performance of cauliflower based intercropping system. The experiment consisted of 7 treatments, where one with sole cauliflower as monocrop and in the remaining six French bean, pea, beet, carrot, palak and coriander were included as intercrops with the cauliflower. The experiment was laid out in the randomized block design with three replications. Sole crop of cauliflower recorded the highest performance for all the growth characters, yield attributes and yield. Whereas, inclusion of legumes in intercropping system was helpful towards improvement of physical as well as bio-chemical properties of cauliflower curd. LER also improved with legume intercropping. However, the combined gross biomass production, net return in monetary value and $\mathrm{B}$ : $\mathrm{C}$ ratio were at a bit higher side with cauliflower + beet, cauliflower + carrot and cauliflower + coriander intercropping system. The study directed towards the fact that intercropping with root crops may be advocated for more return per unit area, while to get promising quality of cauliflower legume intercrops are always preferable.

\section{Introduction}

In India major land is devoted for cereals and only $3 \%$ area of our total arable land is used for vegetable production. The per capita per day consumption of vegetable in India is on an average 125-130 g, but Indian Council of Medical Research recommended taking 285$300 \mathrm{~g}$ of vegetable every day. To meet this requirement we have to produce 220 million tonnes of vegetable in $2020 \mathrm{AD}$ from the present production level. In this direction, the only solution is to increase vegetable production and productivity per unit area per unit time through growing improved high yielding varieties, adequate and scientific crop management practices and increasing cropping intensities following different cropping patterns.

Among the different cropping systems like multiple cropping, intercropping, relay cropping, succession cropping, intercropping is the most suitable practice to stabilize the production. According to Willey (1979), intercropping is the growing of two or more crops/varieties simultaneously on the same area of land. The crops may or may not be sown or harvested at the same time. Most important advantage of intercropping is that it 
is more efficient and productive than sole cropping due to its higher combined yield. The risk due to weeds, disease, pests and climatic factors are reduced in the intercropping (Arnon, 1975).

The West Bengal State is currently the leading producer cauliflower (22\%) in India (NHB, 2014). Cauliflower (Brassica oleracea var. botrytis) is widely used in salads, boiled vegetable, cooked in curries, pickling as well as dehydrated vegetable. Cauliflower is medium to long duration crop. Very short duration vegetables and other crops can be efficiently taken up in the field of cauliflower for better utilization of growth resources. In this regard on the basis of important considerations of intercropping some vegetable crops viz., French bean, pea, beet, carrot, palak, coriander were selected as suitable intercrops to be grown with cauliflower.

The information for wider adaptability of the said intercrops with cauliflower towards improving vegetable production has not yet been exploited. In the light of the above, the objective of the study was to evaluate the performance of cauliflower based intercropping system with respect to crop growth, yield attributes, yield and quality of cauliflower as well as economic feasibility due to sole crop and interactive effects of intercrops.

\section{Materials and Methods}

The experiment was conducted at Horticulture Research Station, Mondouri of Faculty of Horticulture, Bidhan Chandra Krishi Viswavidyalaya, Mohanpur, Nadia, West Bengal during winter seasons of 2013-2014 and 2014-2015. The research station is situated at $23.5^{\circ} \mathrm{N}$ latitude and $89^{\circ} \mathrm{E}$ longitude with an average altitude of $9.75 \mathrm{~m}$ above mean sea level. The soil of the experimental field was alluvial in nature and sandy loam in texture with good drainage and water holding capacity and aeration. The soil was almost neutral in reaction with a $\mathrm{pH}$ of 7.2 and having $0.39 \%$ organic carbon, $0.06 \%$ total nitrogen, available phosphorous $23.11 \mathrm{~kg}$ $\mathrm{ha}^{-1}$ and available potassium $185.62 \mathrm{~kg} \mathrm{ha}^{-1}$. The experimental site is situated near the Tropic of Cancer. The average temperature ranges from $25-36.5^{\circ} \mathrm{C}$ during summer and $12-25^{\circ} \mathrm{C}$ during winter months with average rainfall is about $1500 \mathrm{~mm}$.

The experiment was laid out in a Randomized Block Design with seven treatments i.e. $\mathrm{T}_{1}-$ cauliflower - grown as a sole crops, $\mathrm{T}_{2}$ cauliflower + French bean, $\mathrm{T}_{3}$ - cauliflower + pea, $\mathrm{T}_{4}$ - cauliflower + beet, $\mathrm{T}_{5}$ - cauliflower + carrot, $\mathrm{T}_{6}-$ cauliflower + palak and $\mathrm{T}_{7}-$ cauliflower + coriander. Each treatment was replicated thrice and the experimental field was divided into three blocks and each of them was further sub divided into seven plots. The experiment was conducted with cauliflower cv. Pant Subhra (from GBPAUT, Pantnagar) and variety Falguni (from Seminis Monsanto holding Pvt. Ltd.), PSM-3 (from Bangalore Seeds Pvt. Ltd.), Globe Red (from B.K Seeds Pvt. Ltd.), Early Nantes (from IARI, New Delhi), Pusa Bharti (from IARI, New Delhi) and Mohanpur local (from Mohanpur, Nadia, W.B.) were used for French bean, pea, beet, carrot, palak and coriander, respectively.

Cauliflower seeds were sown in the field at a spacing of $60 \mathrm{~cm} \times 60 \mathrm{~cm}$ in plots of $3.0 \mathrm{~m} \mathrm{x}$ $3.0 \mathrm{~m}$ size. Number of plants per plot was 25 . Normal cultural practices and plant protection measures were followed during the cultivation process. For intercrops thinning was carried out 20 days after sowing of seeds. In case of French bean and pea $10 \mathrm{~cm}$, and for carrot and beet $5 \mathrm{~cm}$ spacing from plant to plant were maintained. No thinning operation was done in case of palak and coriander. The data 
obtained for various characters were analyzed statistically following the methods of Gomez and Gomez (1984), Panse and Sukhantne (1989) and using online software OPSTAT. The Tables formulated by Fishers and Yates (1974) were consulted for comparison of ' $F$ ' values and for determination of critical difference (C.D.) at $5 \%$ level of significance.

\section{Results and Discussion}

\section{Growth and phenological characters}

The experimental results distinctly revealed that plant height, plant spread and stem diameter of cauliflower was influenced to a considerable extent under intercropping with different crops (Table 1). The highest plant height $(48.05 \mathrm{~cm})$, plant spread $(52.17 \mathrm{~cm})$ and stem diameter $(3.14 \mathrm{~cm})$ had been recorded from sole cauliflower $\left(\mathrm{T}_{1}\right)$. The highest stem diameter under sole cauliflower might be due to the fact that it received full advantages of available resource to complete its vegetative growth (Yildrim and Guvenc, 2005). Whereas, relatively higher plant height, plant spread and stem diameter also had been registered from $\mathrm{T}_{2}$ and $\mathrm{T}_{3}$ (i.e. cauliflower + French bean and cauliflower + pea). The advantages of intercropping with legumes have also been demonstrated in numerous studies such as tomato or okra + cowpea (Olasantan, 1991), watermelon + soyabean (Sharaiha and Hattar, 1993) and cabbage + French bean (Poniedzialek and Kunicki, 1995). The significant positive influence of intercrop from leguminous family has also been reported by Agrawal et al., (2010).

Significant differences were observed among the treatments of intercropping systems for leaf number plant $^{-1}$, leaf length and leaf breadth of the cauliflower (Table 1). Comparatively lower number of leaves plant ${ }^{-1}$, leaf length and leaf breadth of cauliflower were obtained when cauliflower was intercropped with palak and coriander. Whereas, the highest values for all these parameters (19.67 plant $^{-1}, 40.90 \mathrm{~cm}$ and 26.34 $\mathrm{cm}$, respectively) had been obtained from $\mathrm{T}_{1}$ (cauliflower grown as a sole crops). Higher number leaves plant- ${ }^{1}$, leaf length and leaf breath in sole cauliflower as compared to the cauliflower + spinach based intercropping system also had been reported by Amoli (2012).

Days to curd initiation under different treatment combinations did not differ significantly. However, it ranged from 63.67 days in case of sole cauliflower $\left(\mathrm{T}_{1}\right)$ to 51.67 days for cauliflower + beet $\left(\mathrm{T}_{4}\right)$ intercropping system (Table 1). Similar results have been observed by Ahmad (1995) in cabbage + tomato and cabbage + batishak based intercropping system.

Higher utilization of nutrients especially nitrogen fertilizers caused higher plant growth and delayed curd initiation in sole cauliflower. The best result with respect to earlier curd maturity had been revealed from cauliflower + coriander $\left(\mathrm{T}_{7}\right)$ based intercropping system which took 93.67 days for the event (Table 1). Longest duration (106.67 days) for curd maturity was recorded from monoculture of cauliflower $\left(\mathrm{T}_{1}\right)$ and it differed statistically from the result of $\mathrm{T}_{7}$, followed by 100.33 days required by cauliflower + French bean $\left(\mathrm{T}_{2}\right)$ and 99.33 days required by cauliflower + pea $\left(\mathrm{T}_{3}\right)$ intercropping system. Higher utilization of nutrients especially nitrogen fertilizers might have caused higher plant growth and consequently delayed curd initiation as well curd maturity in sole cauliflower.

\section{Yield attributes and yield}

Yield attributing characters such as diameter, depth, weight and angle of cauliflower curd 
rendered statistical variation among various intercropping systems. The highest values for all these parameters $19.59 \mathrm{~cm}, 11.93 \mathrm{~cm}$, $961.09 \mathrm{~g}$ and $81.67^{\circ}$, respectively had been registered from $\mathrm{T}_{1}$ (Table 2 ). The result of $\mathrm{T}_{1}$ followed relatively closely by that of $T_{2}$ (cauliflower + French bean) and $\mathrm{T}_{3}$ (cauliflower + pea).

The lowest result in this respect had been visualized from $\mathrm{T}_{6}$ (cauliflower + French bean). However, cauliflower + beet $\left(\mathrm{T}_{4}\right)$ and cauliflower + carrot $\left(\mathrm{T}_{5}\right)$ also produced relatively good result in this aspect. The maximum curd compactness $\left(7.98 \times 10^{-3}\right)$ was registered from $\mathrm{T}_{2}$, which was followed closely by that of $\mathrm{T}_{3}\left(7.86 \times 10^{-3}\right)$.

The $\mathrm{T}_{1}$ (sole cauliflower) produced $24.02 \mathrm{~kg}$ curd plot $^{-1}$ (Table 2) and it was the highest performer for this character. The value of $\mathrm{T}_{1}$ differed significantly from all the other treatments.

However, a relatively higher curd yield per plot of 22.15 and $22.01 \mathrm{~kg}$ had been obtained from cauliflower + French bean $\left(\mathrm{T}_{2}\right)$ and cauliflower + pea $\left(\mathrm{T}_{3}\right)$ based intercropping system, respectively, which were statistically at par among themselves. The lowest curd yield per plot $(19.11 \mathrm{~kg})$ had been recorded from cauliflower + palak $\left(\mathrm{T}_{6}\right)$ based intercropping system.

The recorded yield of cauliflower curd per ha was invariably followed the same trend as compared to that of individual curd weight and curd yield per plot. Here the highest yield of the curd had been recorded from sole cauliflower $\left(T_{1}\right)$ of $226.85 \mathrm{q} \mathrm{ha}^{-1}$.

Lowest curd yield (180.48q ha $\left.\mathrm{ha}^{-1}\right)$ was obtained from cauliflower + palak $\left(\mathrm{T}_{6}\right)$ based intercropping system (Table 2). Relatively higher yield of cauliflower under sole cauliflower system had also been reported by Yildirim and Guvenc (2005). Relatively higher yield of cauliflower par ha have also been recorded from the legume based intercropping systems under this experiment i.e. cauliflower + French bean $\left(\mathrm{T}_{2}\right)$ and cauliflower + pea $\left(\mathrm{T}_{3}\right)$ with the yield of 209.19 and $207.87 \mathrm{q} \mathrm{ha}^{-1}$, respectively. Results of treatments $T_{2}$ and $T_{3}$ did not show any statistical variation from each other.

Almost similar result with respect to incorporation of legume crops as intercrops were also reported by Kanwar and Chopra (1967), Ahmad (1995) and Agrawal et al., (2010). The leguminous intercrops tried in this experiment rendered complementary and helping attitude towards the main crop in achieving relatively higher productivity per unit area (Agrawal et al., 2010).

\section{Quality parameters}

Narrow differences among the total sugar content cauliflower curd of different treatments were noted in the present experiment (Table 3). The highest value in this respect had been recorded from $T_{2}$

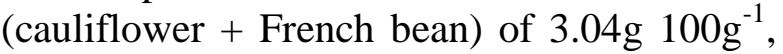
which differed significantly from the other treatments except that of $\mathrm{T}_{3}$ (cauliflower +

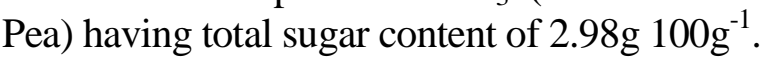

The lowest value of $10.02 \%$ with respect to curd dry matter content had been obtained from $\mathrm{T}_{1}$ (sole cauliflower) (Table 3 ), which differed significantly from all other treatments except that of cauliflower + coriander $\left(\mathrm{T}_{7}\right)$.

The highest reading $(12.85 \%)$ of dry matter was obtained from cauliflower + pea $\left(T_{3}\right)$ followed by cauliflower + French bean $\left(\mathrm{T}_{2}\right)$ with curd dry matter value of $12.29 \%$. these differed significantly from the other treatments expect among themselves. However, treatments failed to register significant influence on ascorbic acid content of cauliflower curd (Table 3 ). 
Table.1 Effect of intercropping on growth and phonological characters of cauliflower (Pooled data)

\begin{tabular}{|c|c|c|c|c|c|c|c|c|}
\hline Treatments & $\begin{array}{c}\text { Plant } \\
\text { height } \\
(\mathrm{cm})\end{array}$ & $\begin{array}{c}\text { Plant } \\
\text { spread } \\
(\mathrm{cm})\end{array}$ & $\begin{array}{c}\text { Stem } \\
\text { diameter } \\
(\mathrm{cm})\end{array}$ & $\begin{array}{l}\text { No of } \\
\text { leaves } \\
\text { plant }^{-1}\end{array}$ & $\begin{array}{c}\text { Leaf } \\
\text { length } \\
(\mathrm{cm})\end{array}$ & $\begin{array}{c}\begin{array}{c}\text { Leaf } \\
\text { breath } \\
(\mathrm{cm})\end{array} \\
\end{array}$ & $\begin{array}{c}\text { Days to } \\
\text { curd } \\
\text { initiation }\end{array}$ & $\begin{array}{c}\text { Days to } \\
\text { curd } \\
\text { maturity }\end{array}$ \\
\hline $\mathbf{T}_{1}$ - Cauliflower (sole crop) & 48.05 & 52.17 & 3.14 & 19.67 & 40.90 & 26.34 & 63.67 & 106.67 \\
\hline $\mathbf{T}_{\mathbf{3}}-$ Cauliflower + pea & 43.43 & 45.89 & 2.88 & 20.56 & 37.80 & 22.99 & 60.67 & 99.33 \\
\hline $\mathbf{T}_{\mathbf{4}}-$ Cauliflower + beet & 37.66 & 40.32 & 2.48 & 13.20 & 32.21 & 19.68 & 51.67 & 96.67 \\
\hline $\mathbf{T}_{7}-$ Cauliflower + coriander & 39.38 & 42.50 & 2.68 & 16.75 & 33.72 & 21.14 & 57.33 & 93.67 \\
\hline S.Em. $( \pm)$ & 1.10 & 1.37 & 0.05 & 0.49 & 0.77 & 0.66 & 2.96 & 2.34 \\
\hline C.D. at $(5 \%)$ & 3.43 & 4.28 & 0.16 & 1.52 & 2.41 & 2.06 & N.S. & 7.31 \\
\hline
\end{tabular}

Table.2 Effect of intercropping on yield attributes and yield of cauliflower (pooled data)

\begin{tabular}{|c|c|c|c|c|c|c|c|}
\hline Treatments & $\begin{array}{c}\text { Curd } \\
\text { diameter } \\
(\mathbf{c m})\end{array}$ & $\begin{array}{c}\text { Curd } \\
\text { depth } \\
(\mathrm{cm}) \\
\end{array}$ & $\begin{array}{c}\text { Curd } \\
\text { weight } \\
\text { (g) }\end{array}$ & $\begin{array}{c}\text { Curd } \\
\text { angle } \\
\left({ }^{0}\right)\end{array}$ & $\begin{array}{c}\text { Card } \\
\text { compactness }\end{array}$ & $\begin{array}{c}\text { Curd } \\
\text { yield plot }^{-1} \\
(\mathrm{~kg})\end{array}$ & $\begin{array}{c}\text { Curd } \\
\text { yield } \\
\left(\mathbf{q} \mathbf{h a}^{-1}\right)\end{array}$ \\
\hline $\mathbf{T}_{1}$ - Cauliflower (sole crop) & 19.59 & 11.93 & 961.09 & 81.67 & $6.25 \times 10^{-3}$ & 26.34 & 63.67 \\
\hline $\mathbf{T}_{\mathbf{3}}-$ Cauliflower + pea & 18.65 & 11.21 & 880.73 & 72.14 & $7.86 \times 10^{-3}$ & 22.99 & 60.67 \\
\hline $\mathbf{T}_{\mathbf{4}}-$ Cauliflower + beet & 14.35 & 8.14 & 775.35 & 78.28 & $6.42 \times 10^{-3}$ & 19.68 & 51.67 \\
\hline $\mathbf{T}_{7}-$ Cauliflower + coriander & 15.84 & 9.57 & 828.93 & 75.82 & $6.96 \times 10^{-3}$ & 21.14 & 57.33 \\
\hline S.Em. $( \pm)$ & 0.67 & 0.31 & 18.44 & 0.35 & 0.0004 & 0.66 & 2.96 \\
\hline C.D. at $(5 \%)$ & 2.09 & 0.97 & 57.45 & 1.08 & 0.0012 & 2.06 & N.S. \\
\hline
\end{tabular}


Table.3 Effect of intercropping on quality parameters of cauliflower (Pooled data)

\begin{tabular}{|c|c|c|c|}
\hline Treatments & $\begin{array}{c}\text { Total sugar } \\
\left(\mathrm{g} \mathrm{100g}^{-1}\right)\end{array}$ & $\begin{array}{c}\text { Ascorbic acid } \\
\left({\left.\mathrm{mg} 100 \mathrm{~g}^{-1}\right)}\right.\end{array}$ & $\begin{array}{c}\text { Curd dry } \\
\text { matter }(\%)\end{array}$ \\
\hline $\mathbf{T}_{1}$ - Cauliflower (sole crop) & 2.52 & 45.32 & 10.02 \\
\hline $\mathbf{T}_{\mathbf{2}}-$ Cauliflower + French bean & 3.04 & 51.61 & 12.29 \\
\hline $\mathbf{T}_{\mathbf{3}}-$ Cauliflower + pea & 2.98 & 49.37 & 12.85 \\
\hline $\mathbf{T}_{4}-$ Cauliflower + beet & 2.63 & 46.70 & 11.48 \\
\hline $\mathbf{T}_{5}-$ Cauliflower + carrot & 2.68 & 46.37 & 11.78 \\
\hline $\mathbf{T}_{6}-$ Cauliflower + palak & 2.62 & 46.02 & 11.40 \\
\hline $\mathbf{T}_{7}-$ Cauliflower + coriander & 2.54 & 45.41 & 11.00 \\
\hline S.Em. $( \pm)$ & 0.12 & 1.89 & 0.32 \\
\hline C.D. at $(5 \%)$ & 0.36 & N.S. & 1.01 \\
\hline
\end{tabular}

Table.4 Combined gross yield and land equivalent ratio (LER) under Different cauliflower based intercropping system (Pooled data)

\begin{tabular}{|l|c|c|c|c|}
\hline Treatments & $\begin{array}{c}\text { Yield of } \\
\text { cauliflower } \\
\left(\mathbf{q} \mathbf{~ h a}^{-\mathbf{1}}\right)\end{array}$ & $\begin{array}{c}\text { Yield of inter } \\
\text { crops } \\
\left(\mathbf{q} \mathbf{~ h a}^{-\mathbf{1}}\right)\end{array}$ & $\begin{array}{c}\text { combined } \\
\text { gross yield } \\
\left(\mathbf{q} \mathbf{~ h a}^{-\mathbf{1}}\right)\end{array}$ & LER \\
\hline $\mathbf{T}_{\mathbf{1}}$ - Cauliflower (sole crop) & 226.85 & - & 226.85 & 1.00 \\
\hline $\mathbf{T}_{\mathbf{2}}$ - Cauliflower + French bean & 209.19 & 20.33 & 229.63 & 1.23 \\
\hline $\mathbf{T}_{\mathbf{3}}-$ Cauliflower + pea & 207.87 & 20.48 & 228.35 & 1.21 \\
\hline $\mathbf{T}_{\mathbf{4}}-$ Cauliflower + beet & 183.03 & 70.00 & 253.03 & 1.14 \\
\hline $\mathbf{T}_{\mathbf{5}}$-Cauliflower + carrot & 197.76 & 65.00 & 262.76 & 1.19 \\
\hline $\mathbf{T}_{\mathbf{6}}$-Cauliflower + palak & 180.48 & 60.00 & 240.48 & 1.12 \\
\hline $\mathbf{T}_{\mathbf{7}}$-Cauliflower + coriander & 195.68 & 20.50 & 216.18 & 1.17 \\
\hline
\end{tabular}

Table.5 Economics of different cauliflower based intercropping system (Pooled data)

\begin{tabular}{|c|c|c|c|c|c|c|}
\hline Treatments & $\begin{array}{c}\text { Return from } \\
\text { cauliflower } \\
\left(\text { Rs. ha- } \mathbf{h a}^{-1}\right)\end{array}$ & $\begin{array}{c}\text { Return } \\
\text { from } \\
\text { intercrops } \\
(\text { Rs. ha-1) } \\
\end{array}$ & $\begin{array}{c}\text { Total } \\
\text { return } \\
\left(\text { Rs. }_{\text {ha }}{ }^{-1}\right)\end{array}$ & $\begin{array}{l}\text { Total cost } \\
\left(\text { Rs. ha }^{-1}\right)\end{array}$ & $\begin{array}{c}\text { Net return } \\
\left(\text { Rs. } \text { ha }^{-1}\right)\end{array}$ & $\begin{array}{l}\text { Benefit } \\
\text { Cost } \\
\text { ratio } \\
\text { (B:C) } \\
\end{array}$ \\
\hline & 1 & 2 & $3(2+1)$ & 4 & $5(3-4)$ & $6(5 / 4)$ \\
\hline $\mathbf{T}_{1}-$ Cauliflower (sole crop) & $1,70,137.50$ & - & $1,70,137.50$ & $59,795.50$ & $1,10,342.00$ & 1.84 \\
\hline $\mathbf{T}_{2}-$ Cauliflower + French bean & $1,56,862.50$ & $44,726.00$ & $2,01,588.50$ & $66,691.75$ & $1,34,896.75$ & 2.02 \\
\hline $\mathbf{T}_{3}-$ Cauliflower + pea & $1,55,902.50$ & $40,960.00$ & $1,96,862.50$ & $61,570.50$ & $1,35,292.00$ & 2.19 \\
\hline $\mathbf{T}_{4}-$ Cauliflower + beet & $1,37,272.50$ & $63,000.00$ & $2,00,272.50$ & $59,513.00$ & $1,40,759.50$ & 2.36 \\
\hline $\mathbf{T}_{5}-$ Cauliflower + carrot & $1,48,220.00$ & $78,000.00$ & $2,26,220.00$ & $65,523.00$ & $1,60,697.00$ & 2.45 \\
\hline $\mathbf{T}_{\mathbf{6}}-$ Cauliflower + palak & $1,35,360.00$ & $48,000.00$ & $1,83,360.00$ & $58,674.25$ & $1,24,685.75$ & 2.12 \\
\hline $\mathbf{T}_{7}-$ Cauliflower + coriander & $1,46,760.00$ & $41,000.00$ & $1,87,760.00$ & $57,803.50$ & $1,29,956.50$ & 2.24 \\
\hline
\end{tabular}

N.B. Market price of vegetables at the time of harvesting: cauliflower (Rs.750.00 q ${ }^{-1}$ ), French bean (Rs. 2,200.00 q $\mathrm{q}^{-1}$ ),

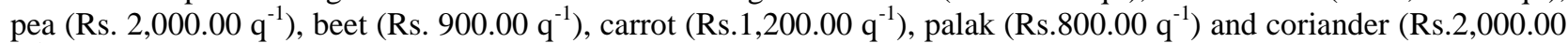
$\left.\mathrm{q}^{-1}\right)$. 
Evaluation of intercropping system with respect to combined gross yield and land equivalent ratio (LER)

Combined gross yield was maximum in cauliflower + carrot $\left(262.76 \mathrm{q} \mathrm{ha}^{-1}\right)$ followed by cauliflower + beet $\left(253.03 \mathrm{q} \mathrm{ha}^{-1}\right)$ based intercropping system (Table 4). Lowest combined yield of $216.18 \mathrm{q} \mathrm{ha} \mathrm{ha}^{-1}$ was found in cauliflower + coriander based intercropping system which was preceded by $226.85 \mathrm{q} \mathrm{ha}^{-1}$ in sole crop of cauliflower.

The combined yield for $\mathrm{T}_{2}$ (cauliflower + French bean) and $\mathrm{T}_{3}$ (cauliflower + Pea) were obtained as 229.63 and $228.35 \mathrm{q} \mathrm{ha}^{-1}$. When the values of land equivalent ratio (LER) appear to be greater than one under intercropping system, this usually indicates the efficiency of this system over the sole cropping system (Vandermeer, 1989).

Intercropping system of cauliflower + French bean followed by cauliflower + pea recorded the most promising result of LER with the values of 1.23 and 1.21 , respectively (Table 4). The high efficiency of intercropping found in this study is in agreement with the findings of Prabhakar and Sukhla (1990), Malhotra and Kumar (1995) and Baumann et al., (2001) who explained this phenomenon by the complementary use of growth resources in vegetable production.

\section{Economics of intercropping system}

The realization of production potential per unit area and time is dependent on investment. Market values play more important role rather than number of crops per unit area and time in determining economic returns.

The present study had indicated that the most economically satisfactory intercropping system was cauliflower + carrot with the net return of Rs. 160697.00 ha $^{-1}$ and benefit cost ratio of 2.45 , the next best result was obtained under cauliflower + beet based intercropping system with net return and $\mathrm{B}: \mathrm{C}$ ratio of Rs.140759.50 $\mathrm{ha}^{-1}$ and 2.36 respectively (Table 5) as in these cases combined gross yield or bio mass production per unit area and unit time was much higher compared to that of other systems. However, other intercrops namely, French bean, pea, and coriander also followed very closely and proved sufficiently lucrative compared to that of sole cauliflower cultivation.

In the present experiment, it had been realized that the growth characters, phenological parameters, yield attributes, yield and quality parameters of cauliflower performed in comparatively better way when the main crop was intercropped with vegetables belong to Leguminosae family (i.e. French bean and pea). Even, intercropping with legume vegetables gave relatively higher LER values also.

However, when the gross yield, net return and $\mathrm{B}: \mathrm{C}$ ratio come into question, it showed carrot, radish and coriander performed a bit better than that of French bean and pea intercropping system. So, from the overall point of view it may be concluded that intercropping in all the cases proved beneficial compared to that of mono culture.

Along with that it may also be mentioned here that as per farmers' preference if the quality of cauliflower curd would be of top priority then the farmers should opt for legumes (French bean and pea) as intercrops for cauliflower. On the other hand if any one searching for higher biomass production per unit area and time along with more income irrespective of quality of cauliflower then he or she may take either carrot or radish as intercrops with cauliflower especially, in the alluvial plains. 


\section{References}

Agrawal, N. S., Kar, D. S. and Mohanty, A. 2010. Intercropping trial in cauliflower cv. Snowball -16. Indian Journal of Horticulture. 67: 314-316.

Ahmad, M. 1995. Study on the performance of tomato + Batisak, Tomato + Cabbage intercropping., Journal of Agricultural Research. 20: 47 - 51.

Amoli, N. 2012. Investigation of intercropping cauliflower and spinach in north of Iran. Technical Journal of Engineering and Applied Sciences. 2(6): 135 - 140.

Arnon, I. 1975. Physiological aspects of dryland farming. In Physiological principles of dry land crop production. (Gupta, V. S., Ed.) Oxford and IBH pub. pp. 95.

Baumann, D. T., Bastiaans, L. and Kropff, M. J. 2001. Competition and crop performance in a leek - celery intercropping system. Crop Science. 41: $764-74$.

Fisher, R. A. and Yates, F. 1963. Statistical Tables for Biological, Agricultural and Medical Research, Longman London, pp. 44-143.

Gomez, K. A. and Gomez, A. A. 1984. Statistical procedure for Agricultural research $\left(2^{\text {nd }}\right.$ Ed.). A Wiley Int. Sci. Pub., New York. pp. 20-30.

Kanwar, J. S. and Chopra, S. L. 1967. Anlysis of fertilizer and manure. Analytical Agricultural Chemistry, pp. 119 - 161.

Malhotra, S. and Kumar, N. 1995. Performance of potato vegetables intercropping systems under dry temperate conditions of north western Himalayas. Indian Journal of Agronomy. 40(3): 394 - 397.

National Horticulture Board, Indian Horticulture Database, 2014. Ministry of Agriculture,
Government of India.

Olasantan, F. O. 1991. Response of tomato and okra to nitrogen fertilizer in sole cropping and intercropping with cowpea. Horticultural Science. 66: 191 - 199.

Panse,V. G. and Sukhatme, P. V. 1985. Statistical methods for Agricultural workers. ICAR, Pusa, New Delhi, 157-165.

Poniedzialek, M. and Kunicki, E. 1995. Suitability of several dwarf French bean cultivars for inter- cropping with late cabbage. ZestytyNaukowse Akademii- Roluicz-im- HugonaW-Krakowie. 22: 5-16.

Prabhakar, B. S. and Shukla, V. 1990. Crop land use efficiency in sequential intercropping systems with vegetables. Indian Journal of Horticulture. 47(4): 427 - 430.

Sharaiha R. K. and Hattar, B. 1993. Intercropping and poultry manure affection yields of corn Water melon and soybean growth in a calcareous. Soil in the Jordan alley. Journal of Agronomy and crop Sciences. 171: 260264.

Vandermeer, J. 1989. The ecology of intercropping. Cambridge university press, Cambridge, U. K. pp. 237.

Willey, R.W. 1979. Intercropping, its importance and research need. Part I. Competition and yield advantages. Field Crop Abstract. 32(1-10): 73-85.

Yildirim, E. and Guvenc, I. 2005. Intercropping based on cauliflower: more productive, profitable and highly sustainable. European Journal of Agronomy. 22: 11 - 18.

Yildirim, E. and Turan, M. 2013. Growth, yield and mineral content of Broccoli intercropped with lettuce. The Journal of Animal and Plant Science. 23(3): 919 922.

\section{How to cite this article:}

Kabiraj, J., R. Das, S.P. Das and Mandal, A.R. 2017. A Study on Cauliflower (Brassica oleracea var. botrytis) Based Intercropping System. Int.J.Curr.Microbiol.App.Sci. 6(7): 25952602. doi: https://doi.org/10.20546/ijcmas.2017.607.306 